\title{
Assessing Monstrous Fan in Malaysia: Present and Future
}

\author{
Raja Nor Firdaus Kashfi Raja Othman 1,2,*(D), Nurfaezah Abdullah ${ }^{1,2}$, Amiruddin Ahamat ${ }^{3}$ (D), \\ Nor Aishah Md Zuki ${ }^{1,2}$, Fairul Azhar Abdul Shukor ${ }^{1,2}$ and Kasrul Abdul Karim ${ }^{1,2}$ \\ 1 Fakulti Kejuruteraan Elektrik, Universiti Teknikal Malaysia Melaka, Durian Tunggal, Melaka 76100, \\ Malaysia; faezah_Abdullah@ymail.com (N.A.); aishahmdzuki@gmail.com (N.A.M.Z.); \\ fairul.azhar@utem.edu.my (F.A.A.S.); kasrul@utem.edu.my (K.A.K.) \\ 2 Electrical Machine Design, Power Electronics and Drives Research Group, CeRIA, UTeM, Melaka 76100, \\ Malaysia \\ 3 Fakulti Pengurusan Teknologi dan Teknokeusahawanan, Universiti Teknikal Malaysia Melaka, \\ Kampus Teknologi, Ayer Keroh, Melaka 75450, Malaysia; amiruddin@utem.edu.my \\ * Correspondence: norfirdaus@utem.edu.my; Tel.: +606-270-2112
}

Received: 11 December 2018; Accepted: 25 January 2019; Published: 6 March 2019

\begin{abstract}
In the last few years, the monstrous fan has gained attention in this country for large space buildings and areas. The continuity of this product technology is important to allow it to be able to survive in the current and future market. However, there are limited studies on the present and future scenario of the monstrous fan, especially in Malaysia. Thus, the objective of this paper is to forecast its present technology, evaluating the market demand and future of the monstrous fan. For these reasons, an online survey was used to obtain feedback from suppliers and manufacturers to forecast the future of this product. In conclusion, the monstrous fan has been discussed and predicted, which can be beneficial for various parties including policy makers, government, business and technology players by representing a specific knowledge on the technical specificities of monstrous fans in Malaysia.
\end{abstract}

Keywords: monstrous fan; HVLS; giant fan; large building; forecasting

\section{Introduction}

The world consists of various continents which cover various countries. Each of the continents has a different climate, influenced by geographical factors in some areas. The world climate is comprised of 12 clusters of 6 different zones, which are zones A, B, C, D, E, and F. Zone A can be found along the equator, which has an equator climate. As depicted in Figure 1, the climograph for zone A temperature and the range of rainfall are fair throughout the year. The average temperature of zone $\mathrm{A}$ is around $26-27^{\circ} \mathrm{C}$. While in zone B, the climate is a tropical monsoon. The tropical climate of Sudan is a hot desert climate, which is dry because of the latitude location far from moisture-bearing winds. Usually, this climate can be found in North Africa and the interior of Southern Africa. Sometimes the B climate can be found in Central Asia, like in China. For zone C, the climate is a moderate to a hot climate that is typically $30{ }^{\circ} \mathrm{C}$ to $45^{\circ} \mathrm{C}$. Other climates are the West Mediterranean climate, Middle continental (Steppe Type), and Eastern suburbs (Chinese Type). These types of climates can be found in large areas in the Northern Hemisphere to lesser of the south of equator line. Zone D is located in cold areas that cover the Western edges (British type), Central continental (Siberian Type), and Eastern edge. Zone D climate occurs around the mid-latitudes, which exist in Northern America and Asia. Another zone is a cold zone, which is zone E, and it exhibits an Arctic polar climate (Tundra type). The other zone is $\mathrm{F}$ zone, which is alpine climate [1]. 

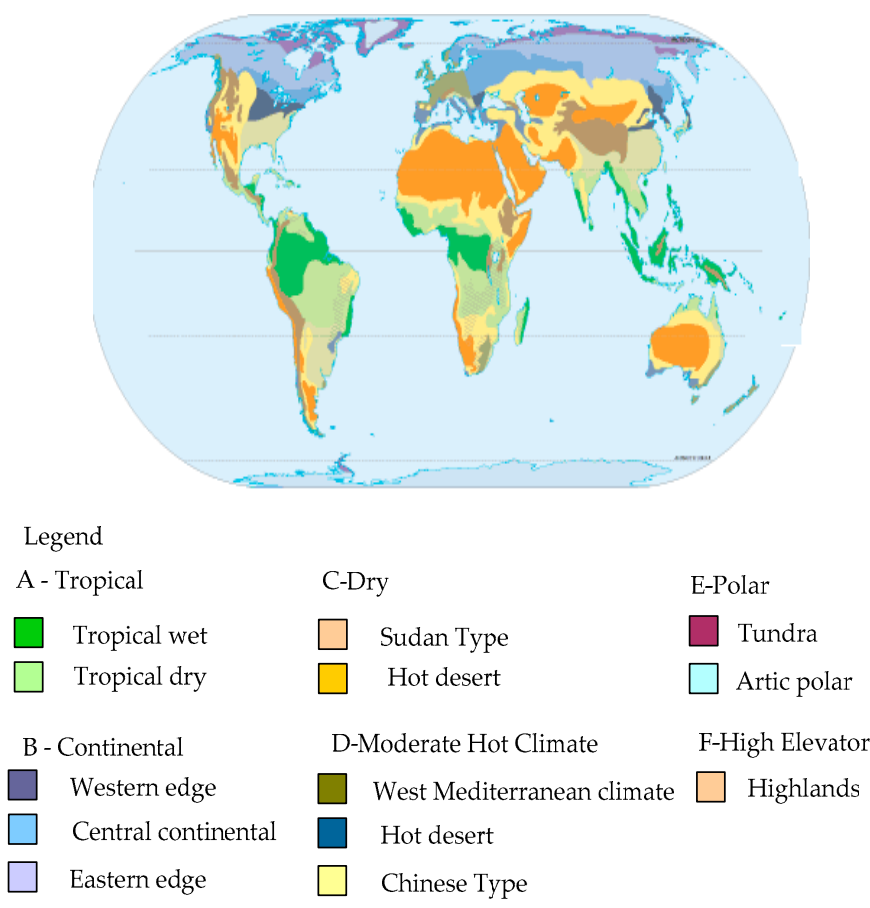

Figure 1. World climate overview.

Besides Indonesia, Sri Lanka, Brazil, Uganda, Colombia, Brunei, Singapore and the Philippines, Malaysia also experiences an equatorial climate because it is positioned in the $\mathrm{A}$ zone along the equator belt. In zone A, the countries will face uniform temperature, high humidity, and copious rainfall in a year. The temperature is high and stable except during the end of the year. For these reasons, there has been a tremendous study of the thermal and ventilation systems that could bring better life improvement for society in these areas [2-6].

Uniquely, the fluctuating high temperatures makes Malaysia's climate relatively hot, especially in several major states in Malaysia. Thus, the conventional fan is used to produce wind in order to provide a refreshing effect when the air is hot. This appliance is affordable and acts as an alternative way to increase the thermal comfort amongst the population in Malaysia. However, the conventional fan is only suitable for small space areas. For the past few years, the conventional fan has been revolutionized by the monstrous fan. The application of a monstrous fan is suitable for large space areas. In Malaysia, this product was introduced in 2007. Yet, there is still limited study on the present and future scenario of the monstrous fan in Malaysia. Hence, the objective of this paper is to assess its present technology, market demand, and its future in Malaysia. To ensure real feedback, an online survey was conducted to gather feedback from suppliers and manufacturers about the monstrous fan in Malaysia. The online survey was conducted and sent through e-mail to all fan manufacturers and companies, and directly to company managers. All data collection was designed to gather information from manufacturers or suppliers based on the fan's technical information and market demand. The overall findings from the survey will be discussed in this paper to predict the future of the monstrous fan. Thus, this paper will include an overview of the monstrous fan, a monstrous fan technology review, the Malaysian market demand, and a monstrous fan forecasting analysis for the future. In the end, this study can be of use for other countries in Zone A.

\section{Monstrous Fan Overview}

A monstrous fan is a mechanical type ceiling fan with a large diameter blade, which is normally mounted from the ceiling. The size is typically contrasted to the conventional fan, which has a diameter of greater than seven feet as shown in Figure 2a below [7]. The larger diameter fan blades provide a large amount of air, which is a key factor if this product is to become popular. The monstrous fan 
was developed according to the principle of air movement and improvement of fan efficiency [8]. In a building or a large space area, the ventilation system is vital to provide fresh air and to remove the heat in such a spacious area. The monstrous fan provides a high volume of air movement at low rotational speed. In fan law, air flow is proportional to the speed, while power is proportional to a cube of change in fan speed [9]. Thus, a low speed rotational fan was designed according to the logical physics of air movement, which requires a less powerful motor.

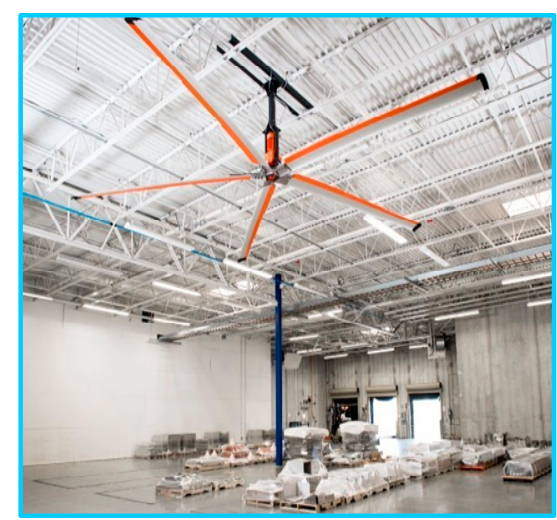

(a)

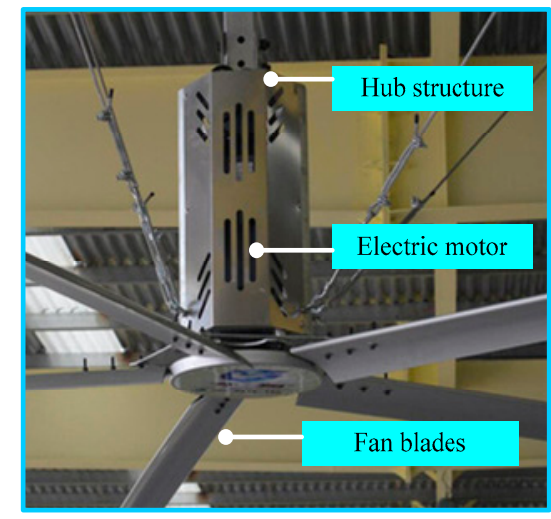

(b)

Figure 2. Monstrous fan (a) Physical condition [10] (b) Common structure.

\subsection{Blade Technologies}

Efficiency plays an important role in selecting a fan. The fan blades act as the main component to push the air downward and provide a comfortable feel in the selected areas. The fan blade profile is one of the major factors involved in increasing fan efficiency. Previously, as in Figure 3a, the conventional fan blades have a flat and fixed nominal tilt design. The flat design is cheaper and requires fewer times constraint to produce it. But it also has a few disadvantages, which are due to the profile shapes not being effective at distributing air and poor performance of the fan blade configurations, which lead to large losses [11]. Thus, much improvement had been done to enhance the fan's efficiency. One of the improvements in the concept design of airfoil fan blades is shown in Figure $3 b$. In a monstrous fan, the profile of the blade is designed with a variety of shapes and styles from various technologies and fan blade profiles.

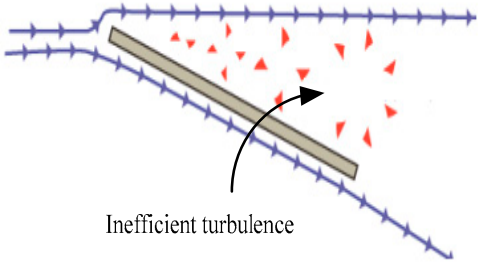

(a)

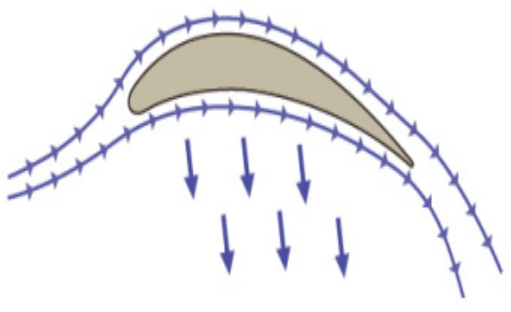

(b)

Figure 3. Technology of monstrous fan blades profile (a) Flat shape concept; (b) Air foil shape.

Since 1998, the airfoil blades technology efficiency was tested in parallel with the first prototype of the HVLS fan [12]. The airfoil style has advantages to increase efficiency by minimizing the flow separation and absorb the energy lost to the air turbulence. In 2001 the commercial airfoil blades were introduced in monstrous fan prototype. The blades technology with larger airfoil shape has impacted the air flows of the fan. The air distribution depends on the rotational direction of the fan. The fan blade is designed according to the concept of air flow, which is adapted from the right-hand rule. 
The concept of the right hand is like a curled finger, acting as the spinning direction as well as the fan blade direction, which rotates to push the air according to the pointing thumb direction $[13,14]$.

In 2006, the Macro Air manufacturer had made the move to improve the efficiency of the monstrous fan by attaching the basic aerodynamic design to the blade design. The manufacturer came out with the whisper foil XL blade, as seen in Figure 4a. The study of the fan blades' design was the idea of the co-founder of Macro Air, who envisioned a fan similar to the airfoil shaped wing of a race car. The race car airfoil has a wing on a rounded leading edge at the front and a thinner edge at the back, while the top has more curves but less at the bottom side. This concept will ensure less air pressure on the above side and result in more air distribution to go down. Besides that, Bladetec manufacturer proposed the complex contoured shape of the fan blades, as in Figure $4 \mathrm{~b}$ below. The blade design has a narrow tip at the bottom edge and an aerodynamic shape at the top of the edge. The shape increases the blade velocity and provides a wide hub area so that the blade velocity will decrease and produce consistent air movement.

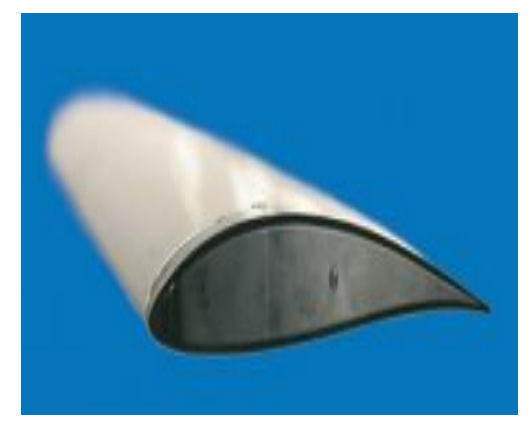

(a)

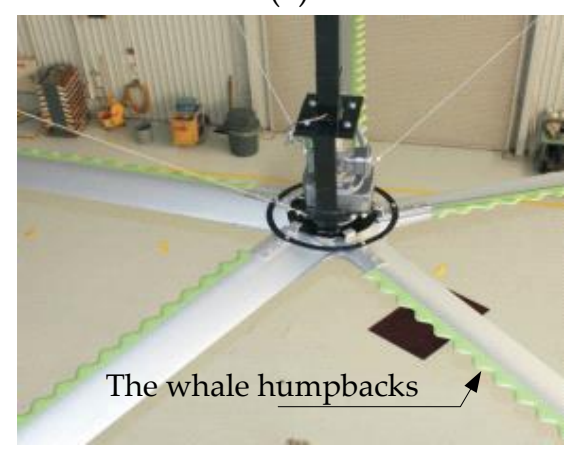

(c)

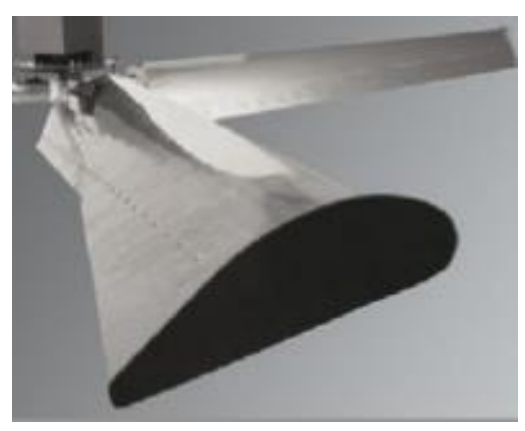

(b)

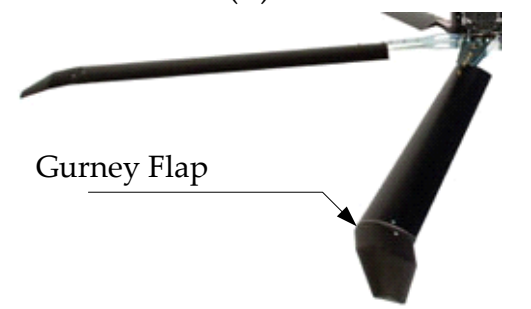

(d)

Figure 4. Other blade technologies (a) Whisper Foil XL Blade (Macro Air) (b) Complex contour shapes [15] (c) Tubercles fan blades [16] (d) Gurney flap.

Figure 4c shows the design of the tubercles technology fan blades, which are based on the natural aerodynamic concept from 2004 by Dr Frank E. Fish and Dr Watts [16]. The design was based on the tubercles on the leading edge of the flippers of a humpback whale. These fan blade designs create more air movement using fewer blades. This is because of the pitch shapes of the humpbacks, which are able to give more lifts and reduce the air turbulence to generate flow between the bumps. Different concepts of airfoil, such as wicker bill technology or a gurney flap are also used to improve the efficiency of the monstrous fan [17]. This gurney flap design as in Figure $4 \mathrm{~d}$ has advantages to produce the downwash to the airfoil blades and increase the percent of air flow distribution with minimal power consumption. The blade's design later develops for the large area, which required full air distribution movement. Table 1 shows a summary of the fan blade design, which is generally manufactured from previous to current. Beginning with the flat fan blade design, the airfoil blade design and the fan blades have developed slowly, evolving to increase efficiency. The development of fan blades is critical to sustaining an air flow balance and increasing the air flow for maximum coverage. 
Table 1. Blades design of the monstrous fan.

\begin{tabular}{llll}
\hline \multicolumn{1}{c}{ Blades Profile } & \multicolumn{1}{c}{ Flat Design } & \multicolumn{1}{c}{ Airfoil Shapes } & \multicolumn{1}{c}{ Complex Shape } \\
\hline \multirow{2}{*}{ Advantages } & $\begin{array}{l}\text { Inexpensive compared to } \\
\text { airfoil blades; Easier to } \\
\text { manufacture due to simple } \\
\text { construction }\end{array}$ & $\begin{array}{l}\text { Increased efficiency; } \\
\text { Provides less air pressure on } \\
\text { the above side and pushes } \\
\text { more air distribution down }\end{array}$ & $\begin{array}{l}\text { Increase blade velocity; } \\
\text { Consistent air movement } \\
\text { due to the wide hub area }\end{array}$ \\
\hline \multirow{2}{*}{ Disadvantages } & $\begin{array}{l}\text { Not effective to distribute } \\
\text { the air; Poor performance; } \\
\text { Large losses }\end{array}$ & - & $\begin{array}{l}\text { Need number of blades } \\
\text { to compensate }\end{array}$ \\
\hline
\end{tabular}

\subsection{Electric Motor}

The electric motor is considered to be the primary mover of the large ceiling fan. The electric motor is located in between the fan blades and the mounting system. Previous technologies of various types of electric motor have been developed for this application [17-19]. One is the Induction Motor (IM). Previously, the table fan type or small ceiling fan used a single phase induction motor to propel the system [20-23]. IM architecture consists of stator and rotor parts, as seen in Figure 5a. The fan will rotate since the magnetic flux induces the sequential current, which excites the coil arrangement. IM has several advantages, it is robust and able to function in any condition. This machine has a simple construction, is inexpensive due to the absence of brushes, which make it more reliable. Thus, it indirectly increases the machine demand from the manufacturer compared to other types of machine. There are a few advantages on this motor, such as a less efficient motor when compared to the BLDC motor, less of a power factor, and the motion will generate heat that can reduce the efficiency of the motor.

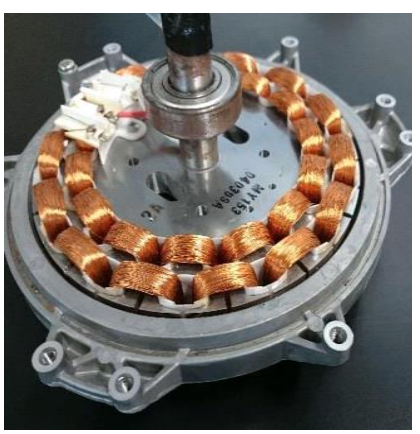

(a)

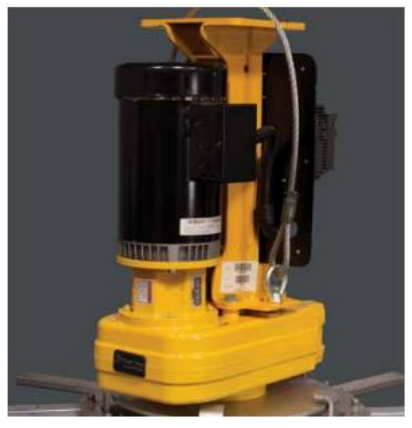

(b)

Figure 5. Induction Motor Technologies Induction Motor architecture (b) AC Induction Motor.

The early emergence of the monstrous fan, called the Big Ass Fan, uses the IM for high volume low-speed fan production [24]. The motor is designed named power foil X2 plus with $2.0 \mathrm{hp}$ output power as in Figure 5b. The structure of the motor requires a gearbox filled with oil and has heavyweight structure due to the custom gearbox. This design has a few disadvantages due to the large, loud, heavy, custom gearbox; or less powerful DC motor.

Another type of electric motor that relates to this application is the Permanent Magnet Synchronous Motor (PMSM). N.F. Zulkarnain et. Al, as in Figure 6a proposed a design concept of a single rotor double stator for ceiling fan application [25]. This design comprises a permanent magnet attached to the rotor part for both motor and generator. Basically, these concepts consist of two systems in one machine, which is a motor and generator. The generator will act as the energy harvester. The aim of this design is to use the wasted kinetic energy, which comes from the rotation of the rotor to convert the energy from mechanical to electrical energy. Thus, the energy can be used again to run the fan. 


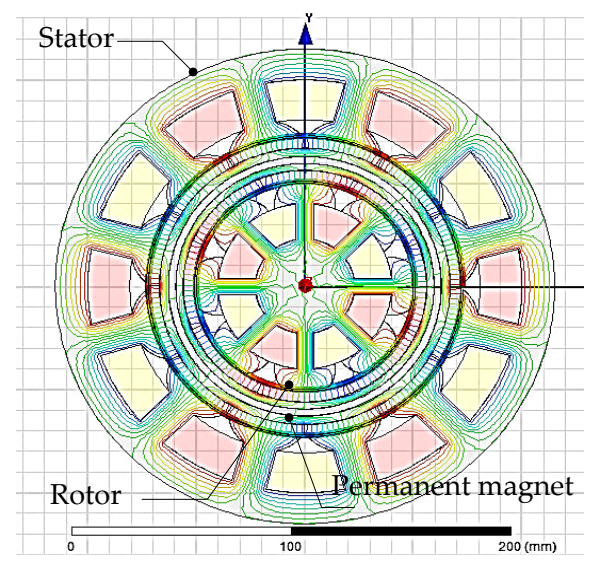

(a)

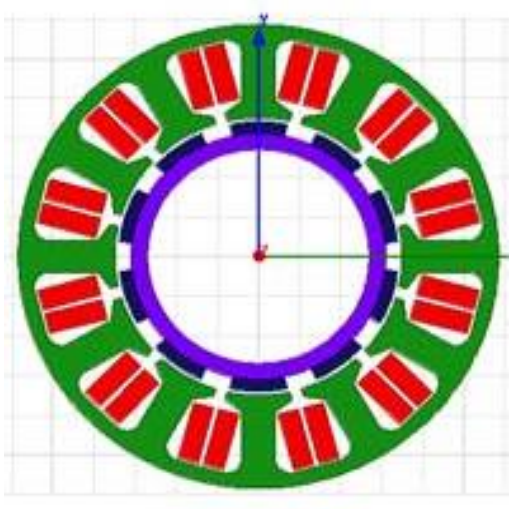

(c)

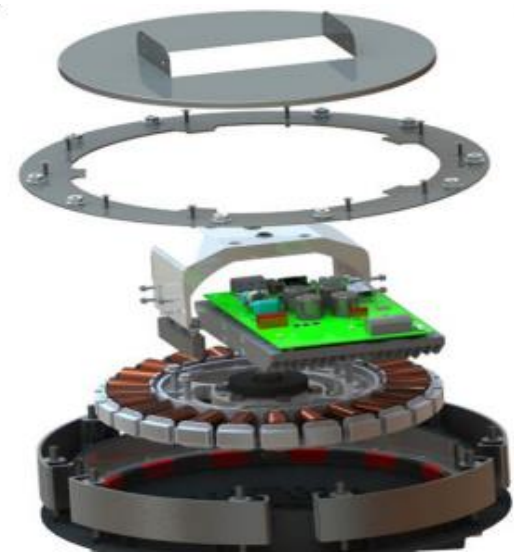

(b)

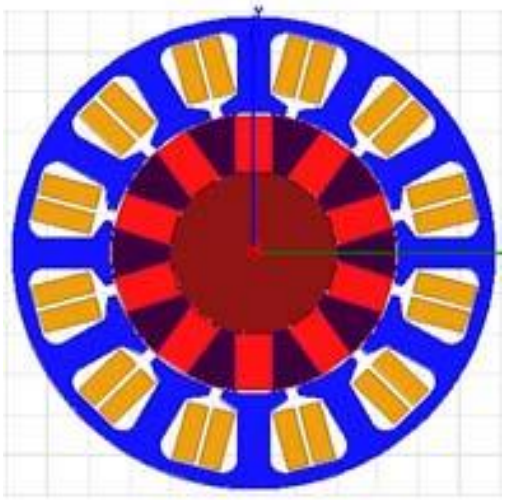

(d)

Figure 6. Monstrous fan with permanent magnet motor technology (a) Double stator (b) Universal Permanent Magnet Synchronous Motor (PMSM) motor [26] (c) Surface mount (d) Spoke type interior permanent magnet (IPM).

In the year 2017, Falco eMotor patented the universal permanent magnet synchronous motor for a HVLS fan product, shown in Figure 6b. This patent was invented using an outer rotor PMSM topology without using a gear attached to the fan. The motivation of this invention basically comes from the problem of using the outdated concept of IM, which can cause noise and vibration, and a steadily gained prominence by PMSM characteristic. Other than that, the design is a rejuvenation effort to improve the PMSM machine in fan application. This new algorithm will let the motor operate either in the AC or DC condition. Mohammad Samadian et. al in his paper chose two permanent magnet machine types, which are the surface mount type (SPM) and the interior permanent magnet spoke type (IPM), to study the performance comparison for an axial fan application as shown in Figure 6c,d [27]. The spoke type IPM is able to produce high power densities in the air gap. The SPM has the advantage in terms of yield, high torque density and efficiency, which comes from the magnetic torque. This study anticipates the results from both types in terms of speed, efficiency, and stack length. But in terms of the weight and cost, the IPM has $45.4 \%$ less than SPM.

The BLDC motor is not new in fan application. This machine technology is intended to conquer the application alongside the growth of power electronic technology. Today the user requires the appliance to be energy efficient and reduce electricity consumption and the same time be able to give higher efficiency. BLDC has good characteristics in terms of higher efficiency, compactness, and is able to produce less noise. Chuan-Sheng Liu et. al proposed a new structure of BLDC motor [28]. According to the design in Figure 7a, the new structure basically has 8 poles and 12 slots with an external rotor topology based on the theory of the BLDC servo motor. The aim of this design is to 
reduce the manufacturing cost and improve energy efficiency. The findings show that this design is able to save $50 \%$ energy and able to reduce the manufacturing cost. A transverse flux motor (TFM) is an electric motor that consists of a rotor, stator, and coil. TFM works when the magnetic flux path with the section is transverse to the direction of the motion. The structure of TFM is basically a simple toroidal coil with the stator wrapped around the coil. The single toroidal coil per phase can enable the low winding resistance due to the high pole counts. This will let the machine produce constant torque, which is equivalent to the size and weight. This machine increases fan efficiency over $80 \%$ and is suitable for direct drive configurations. But this design has a few problems in terms of the noise that comes from the drive systems.

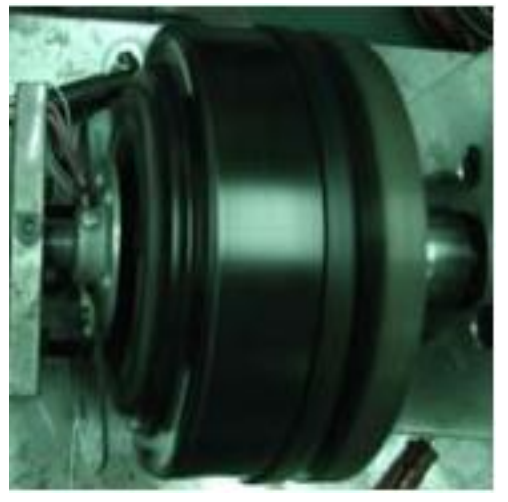

(a)

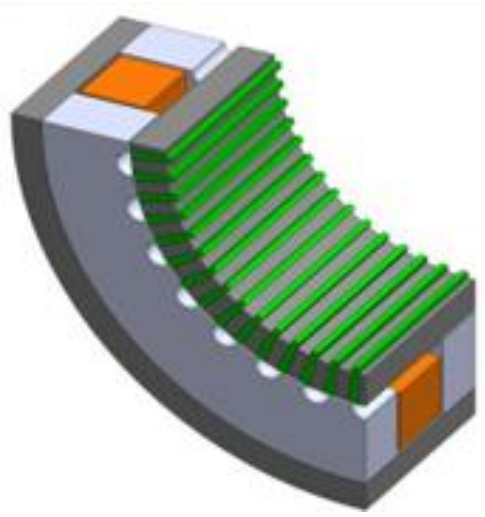

(b)

Figure 7. Monstrous fan with permanent magnet transverse flux motor technology (a) Outer rotor BLDC motor (b) transverse flux motor (TFM) by the ETM Company.

The Electric Torque Machine Company introduced their high-efficiency transverse flux motor fan in the year 2015, as shown in Figure 7b [29]. The design provides a reduced weight when compared with the conventional induction motor and brushless DC motor. This type of motor is suitable for fan application due to low revolutions per minute but a higher efficiency. The motivation of this design is to comprise the bulky machine while at the same time be able to offer the high efficiency necessary to drive a fan system. A transverse flux motor consists of a ring-shaped lamina stator, which is configured by a plurality of radially extending members extending out from an inner stem portion or in from an outer stem portion. The fan blades are directly joined with an outer rotating rotor of the transverse flux motor and the blades are coupled to the stator whilst the rotor is configured within the ring-shaped rotor. Table 2 shows the electric motor, ranging from standard to the present improvement. From previous developments in fan technology until now, the induction motor is the main choice from the manufacturer, but the emerging improvement technology in BLDC and TFM makes both types of motor an alternative in monstrous fan applications.

Table 2. The electric motor for monstrous fan application.

\begin{tabular}{|c|c|c|c|c|}
\hline View & IM & PMM & BLDC & TFM \\
\hline Advantages & $\begin{array}{l}\text { Constant airflow; } \\
\text { Cheaper than DC } \\
\text { motors }\end{array}$ & $\begin{array}{l}\text { Higher horsepower; } \\
\text { than AC motor; Flat } \\
\text { torque over wide } \\
\text { speed range }\end{array}$ & $\begin{array}{l}\text { Most energy efficient; } 70 \% \\
\text { less energy than AC } \\
\text { motors; Stillness, because } \\
\text { of a lack of friction; Longer } \\
\text { life span compared PMM } \\
\text { motors; Gearless }\end{array}$ & $\begin{array}{l}\text { Smaller, and more efficient; } \\
\text { Generates same peak } \\
\text { torque and three times } \\
\text { continuous torque } \\
\text { compared to traditional } \\
\text { BLDC; Gearless }\end{array}$ \\
\hline Disadvantages & Need gear; Noise & $\begin{array}{l}\text { Required gear, produce } \\
\text { noise and vibration }\end{array}$ & Technology still immature & Technology still immature \\
\hline \multicolumn{2}{|c|}{ Standard Technology } & & \multicolumn{2}{|c|}{ Emerging Technology } \\
\hline
\end{tabular}




\subsection{Driving Mechanism}

Usually, there are two types motor drives used in monstrous fans; a geared driven mechanism and direct drive mechanism or gearless driven. A geared motor mechanism, as in Figure 8a is a type of motor that transfers the power to the fan by using a gear mechanism, which is connected to the electric motor and the hub structure [30]. Other than that, the geared DC Motor is used to rotate the ceiling fan down rod or tilt the down rod, further tilting the whole ceiling fan. This type of motor drive is a type of electrical motor that is able to produce high torque while maintaining low horsepower, or a low speed motor output, but it has a few limitations such as noise and vibration due to the connected gear. In meantime, a gearless motor is a type of motor with no gear mechanism required. Without a gear, the system only will be connected directly with the electric motor as in Figure 8b [31]. The advantages to using the gearless motor are high torque productions at low speeds that are more efficient and lack noise and vibrations.

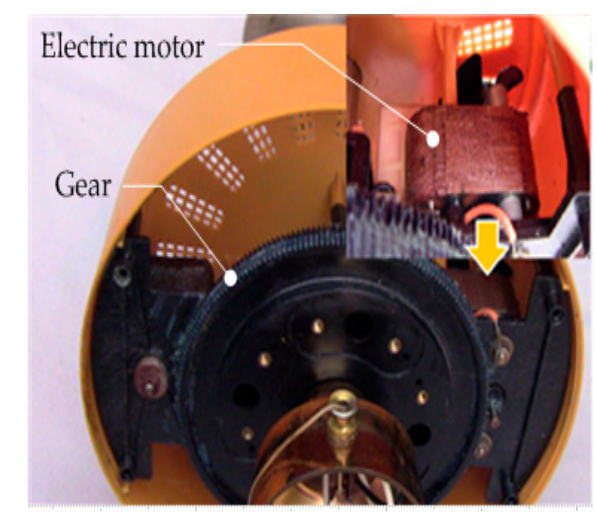

(a)

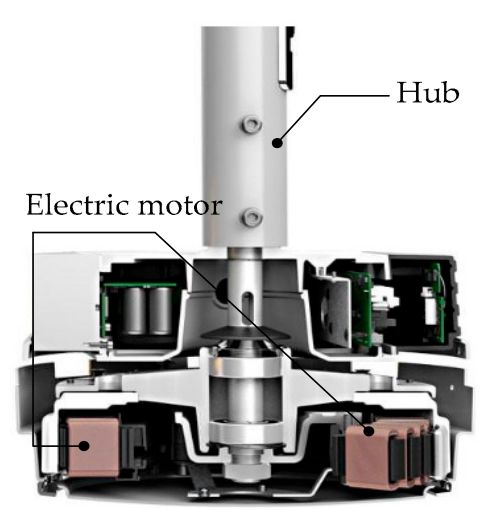

(b)

Figure 8. Monstrous fan driving mechanism (a) Geared mechanism (b) Gearless mechanism.

\section{Present: Market and Sales Information Analysis in Malaysia}

This section explains the sales volume and market contribution of the monstrous fan in Malaysia. Hot and dry weather resulted in the increase of electricity consumption in daily life due to the use of electrical, since as air conditioners reduce the thermal or heat effect. The use of air conditioners will relatively increase the electricity tariff. The demand for the monstrous fan was influenced by the increasing utility tariff as well as the consumer's mind-set in using lesser energy products. This business has seen growth since 2007 until the present and the majority of the pioneer companies started-up in an average of years in this core business. The growth of a company shows a good sign in the monstrous fan market in Malaysia, which contributes to the sales volume. Sales volume can be influenced by various factors such as product features, product technology, and market demand for the product [32].

The monstrous fan comes in various types and features to make it compatible with the environment in Malaysia. Normally, the fan diameter size is more than $16 \mathrm{ft}$. and up to $24 \mathrm{ft}$. Monstrous fan size is determined by two conditions, which are the size of the room and the height of its ceiling. Other than that, the type of motor and fan propeller are also factors. In order to fabricate a fan, the price offered to the customer must be affordable and the manufacturer must be able to make some profit. The transformation in the process of managing research enhances the ability of the manufacturer to learn and to gain access to valuable technology, which could be translated into profit opportunities [33]. Besides that, to compete in this business the manufacturer needs to employ the latest technology in order to sustain their products. Some manufacturers provide their own fan technology to influence end-users. Nevertheless, market demand also encourages the sales volume of the monstrous fan. In another country like the United States, the monstrous fan was initially adopted in agriculture sectors such as dairy farms or barns [34,35]. This is different for the market in Malaysia. Thus, a few surveys 
related to sales volume, market demand, and market size were conducted to collect the data in order to predict the future of the monstrous fans.

The surveys were created by using online documents containing about 25 questionnaires. The scope of the survey consisted of feedback from manufacturers and suppliers of the Monstrous fan, which surrounds the Malaysian country. The survey questionnaires are designed with specific main parameters, such as fan blades, end-user cost, technology features, and market regions to determine geographic factors and a psychographic factor of the monstrous fan. These online surveys include all suppliers and manufacturers in Malaysia. The online survey was conducted and sent through e-mail to all fan manufacturers and companies and directly to company managers. The data has been extracted using excel spreadsheet software. The forecast techniques use moving averaging techniques. Every survey result from each company is analyzed by using tabulated data and plotted using spreadsheet software.

\subsection{Product Features}

Figure 9 a shows the result of monstrous fan sales volume according to fan diameter for the years 2013, 2015, and 2017. For the year 2013, as many as 170 fans of $24 \mathrm{ft}$. diameter were distributed compared to other fan diameters. As in 2013, it showed that monstrous fan sales according to fan diameter are relative to an extended fan diameter, which is $24 \mathrm{ft}$. This shows that customers choose a larger fan diameter for a large scale area to generate a larger air distribution. The second fan diameter that dominates the sales volume is the $16 \mathrm{ft}$. fan diameter, with as many as 140 . In 2015 and 2017, the highest volume of monstrous fan sales was also dominated by the $24 \mathrm{ft}$. fan diameter followed by the $16 \mathrm{ft}$. fan diameter. According to the graph, there is a difference in terms of sales volume for a different year. Earlier in 2013, for all fan diameters, the sales volume was small because the product was still new in the market; however, it increased in the following year. This is because, since 2013, the end users were having difficulty choosing a suitable fan diameter to suit their needs, due to the lack of experience from using this product.

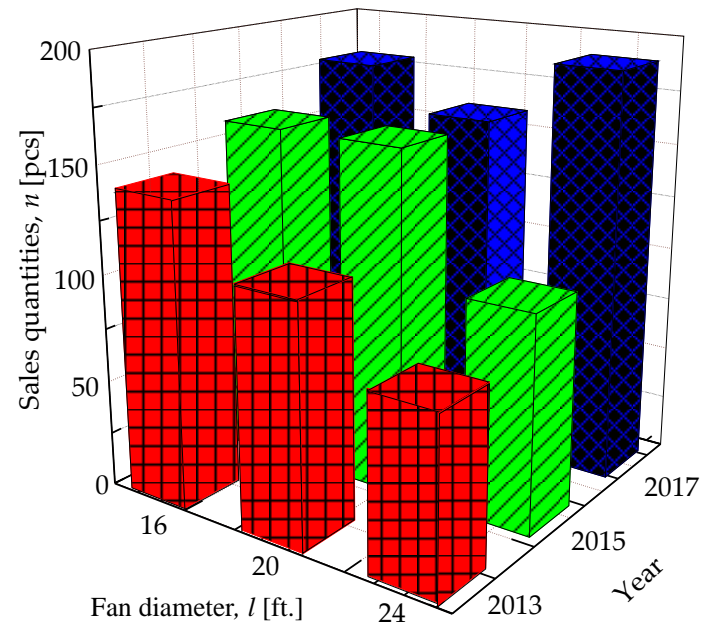

(a)

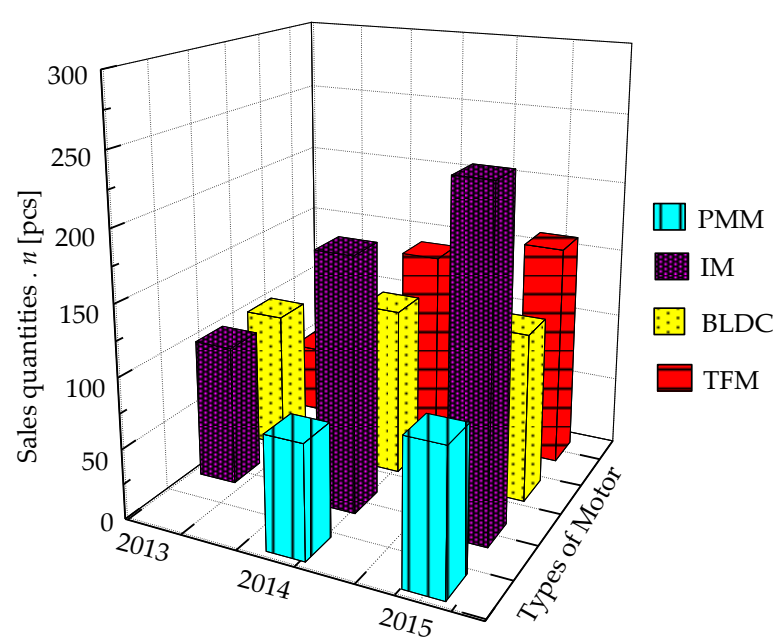

(b)

Figure 9. Product features sales (a) Fan diameter (b) Motor types.

Figure $9 \mathrm{~b}$ shows the findings on monstrous fan sales volume according to motor types for the years 2013, 2015, and 2017. For 2013, many monstrous fans used a Brushless DC motor (BLDC) and Induction Motor (IM) as the propeller for the fan in 100 numbers, respectively. Only 50 numbers used a Transverse Flux Motor (TFM) and others chose other types of motor as the fan propeller. By the year 2015, the induction motor was leading with 180 sales volumes followed by BLDC and Transverse flux 
with 120 and 140, respectively. In this case, even BLDC technology is widely used in the industrial market. But in fan applications, these types of motor are still new and not as accepted. Besides that, only 80 sales quantities of monstrous fan were distributed that used the Permanent Magnet Motor (PMM) as the electric motor. Meanwhile, for the year 2017, the induction motor remains an option as a fan propeller with 240 numbers among the monstrous fan companies. According to the trend line, the quantities distribution of this product is slowly decreasing from year to year, from 2013, to 2017. Instead, the quantities distribution according to type of motor increases from 2013, 2015, and 2017.

\subsection{Technology and Prices Competitiveness}

Figure 10a shows the sales of motor types for every fan diameter. For the permanent magnet type motor (PM), the price for a $16 \mathrm{ft}$. fan diameter ranges from RM 20,000 to RM 35,000. Besides that, for a similar permanent magnet motor type, which has a fan diameter of $18 \mathrm{ft}$., the price is about RM 25,000 to RM 35,000. For a fan diameter of $20 \mathrm{ft}$. to $24 \mathrm{ft}$. the price is about RM 25,000 to RM 40,000. The majority of monstrous fans were comprised of a $16 \mathrm{ft}$. to $18 \mathrm{ft}$. diameter with a price of about RM 15,000 to RM 25,000 and above for each motor type. For a fan diameter of $20 \mathrm{ft}$. to $24 \mathrm{ft}$., the price ranges from RM 25, 000 and above for every motor type. Therefore, it can be said that a larger fan diameter and size of the fan increases the price of the monstrous fan. Figure $9 b$ shows the sales of the monstrous fan according to the fan's technology for five years, from 2013 to 2017. The sales of monstrous fans using motorized gear technology increased from 80 numbers in 2013 to 130 and 230 numbers in 2014 and 2015, respectively. However, in 2016, the sales have decreased to 100 numbers and slightly increased to 380 numbers for the following year. Then, other types of motors, such as the gearless type, have the same sales quantity, which is 30 numbers for each type from the year 2013 to 2015. Most of the monstrous fans used a gear type motor since 2013 because the induction motor was dominantly used. This finding shows that the gearless type monstrous fan is the emerging technology for certain monstrous fan companies in Malaysia.

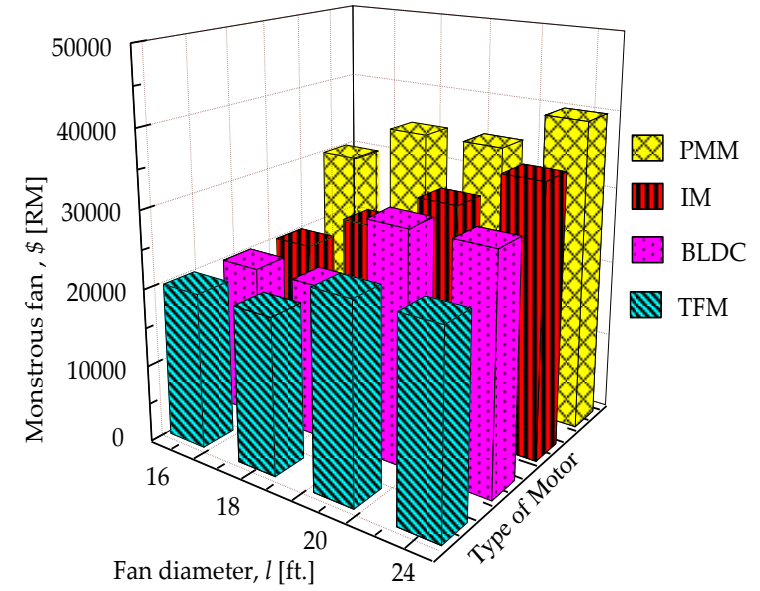

(a)

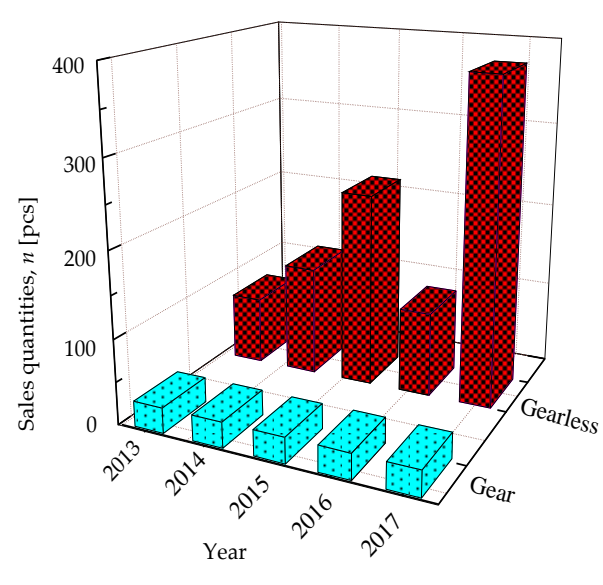

(b)

Figure 10. Technology and price competitiveness (a) Price (b) Fan Technology.

Figure 11a shows the companies' sales of monstrous fans according to market contribution in Malaysia. For the year 2013, 2015, and 2017, dominant sales quantities of monstrous fans distribution by market contribution were from industrial and mosque/prayer halls. This is due to prayer halls and industrial spaces having large areas that require cooling and comfortable surroundings. The lowest market contribution is from the agriculture sector, which is about 60 numbers for three years successively. In Malaysia, the monstrous fan is still new to the agriculture market sector. Usually, 
in the agriculture sector, the monstrous fan will be installed in barns, dairy farms, or horse stables that have a large area and a high building structure from the ground. In Malaysia, not all barn structures and dairy farms are modernized, which affects the sales volume. Hence, based on the trend line, sales volumes in recent years have slightly increased for each market, excluding the agriculture market, airport, aviation, and restaurant. From this, it can be concluded that a monstrous fan is still new in the automotive, aviation, and airport sectors.

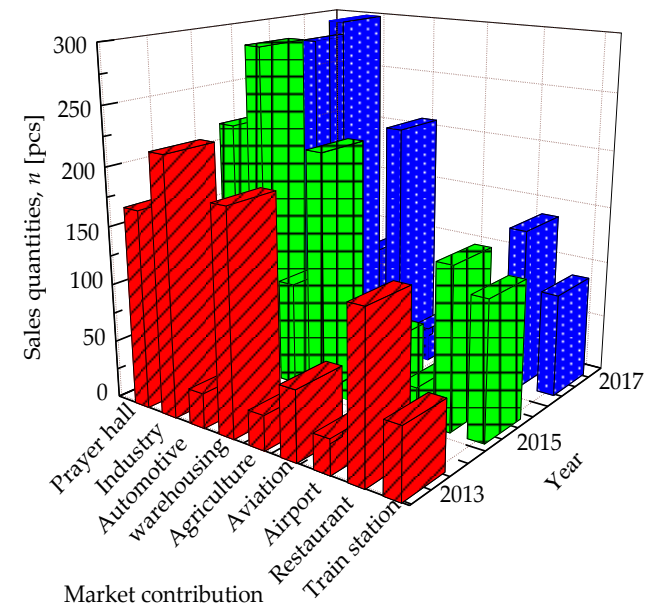

(a)

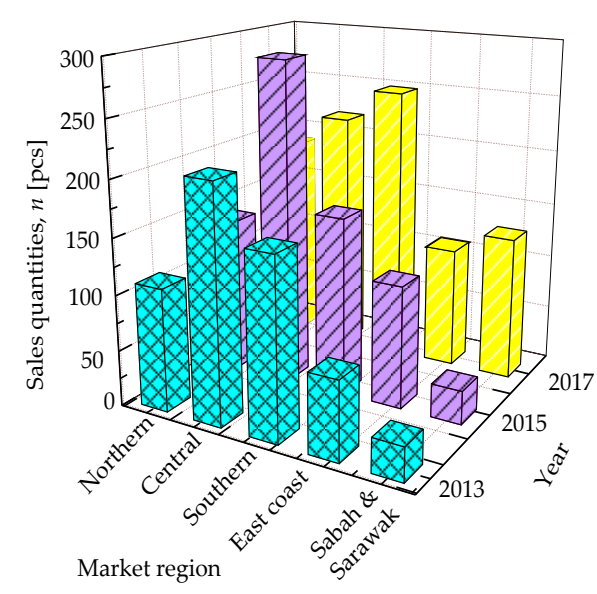

(b)

Figure 11. Local market share (a) Market contribution of monstrous fan (b) Sales region in Malaysia.

Figure $11 \mathrm{~b}$ shows the sales of the monstrous fan according to regions in Malaysia. Based on the chart, it shows that the sales of monstrous fans are concentrated at the central region, which dominated with about 210 numbers for 2013. Here, the central region consists of Selangor, Negeri Sembilan, and Kuala Lumpur. The southern region consists of Melaka and Johor. For the east coast, the regions are Pahang, Kelantan, and Terengganu. For the year 2015, the dominant region for monstrous fan distribution is located in the central region, which is about 280 numbers. This shows that the central region contributes a large amount of monstrous fan sales, because almost all big companies are located at the central region. Thus, the marketing was focused in the central region. For the year 2017, the dominant region is the southern region, with about 250 numbers. But through the trend line, from the years 2013, 2015, and 2017, the quantity distribution of monstrous fans is increasing according to the regions in Malaysia.

Figure 12 shows the sales of the monstrous fan according to fan diameter for the year 2013, 2015, and 2017 in Malaysia. Since the year 2013, only 30 numbers of $16 \mathrm{ft}$. diameters of monstrous fan were sold around the central and southern regions. But for the next two years, the $16 \mathrm{ft}$. fan diameter sales increases by about 50 numbers at the northern region and increases to 60 numbers for the central region. In 2013, the value distributed for the fan diameter of $18 \mathrm{ft}$. is about 30 numbers for the east coast region, Sabah Sarawak, and other regions. While in the year 2015, only 30 numbers were sold at the central region and there was no increase in sales volumes in 2017 for every region. For the $20 \mathrm{ft}$. fan diameter, there were no sales recorded in the year 2013, but in 2015, the sales volumes were about 130 numbers at the central region, 100 quantities each in the southern region, east coast, Sabah and Sarawak, and other regions. Thus, in 2017, the recorded sales volume were about 100 numbers in the northern, 110 in the central region, 160 in the southern region, 110 in the east coast region, and 30 in the Sabah and Sarawak region. 


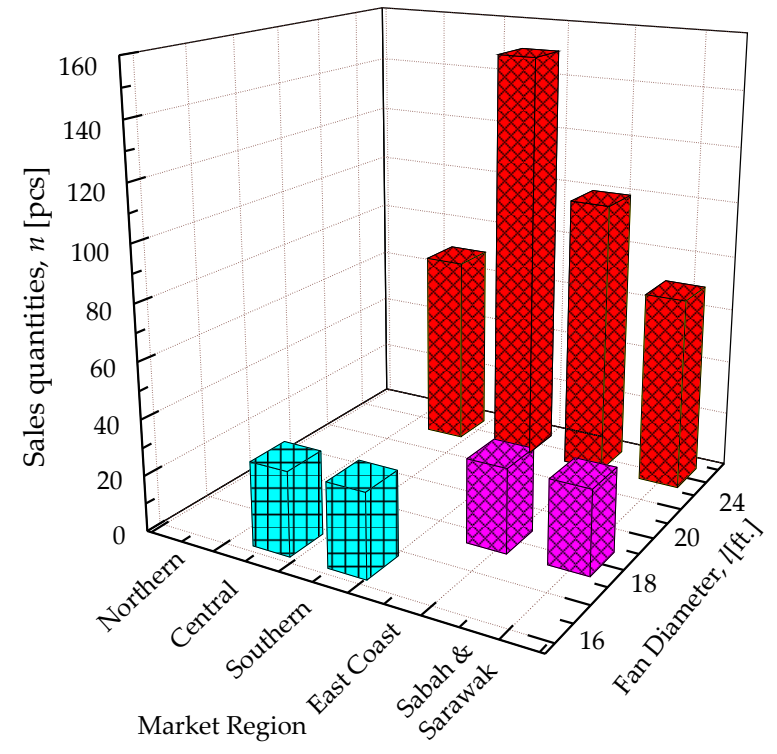

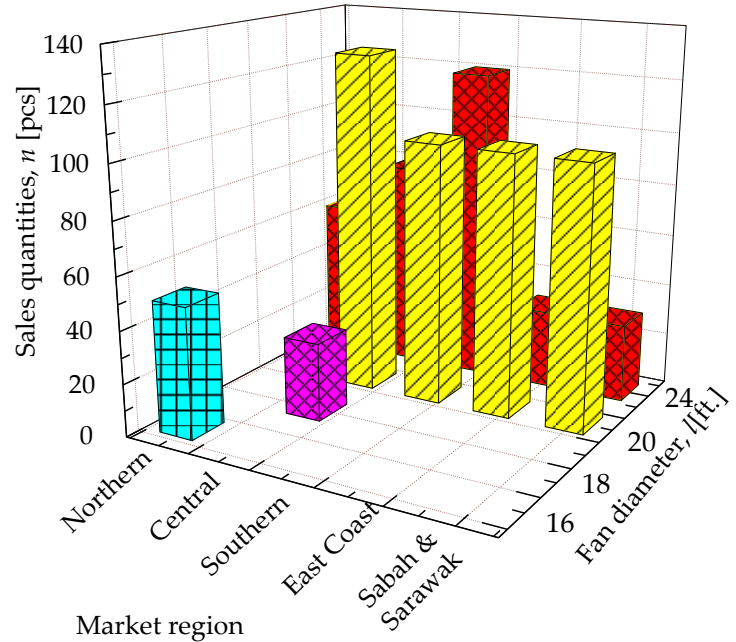

(a)

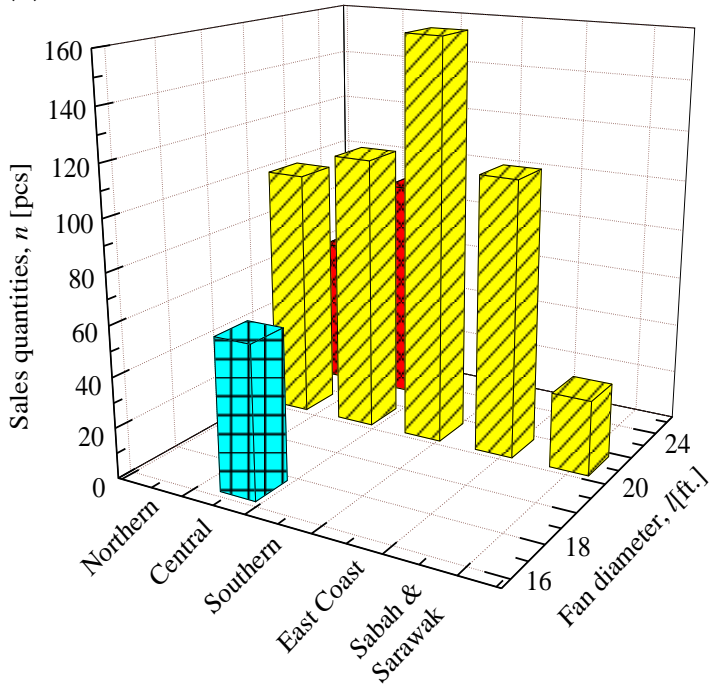

(b)

Market region

(c)

Figure 12. Sales of monstrous fan according to fan diameter (a) 2013 (b) 2015 (c) 2017.

Based on the trend line, in 2013, the $24 \mathrm{ft}$. fan diameter is dominantly distributed at the southern region, but in the year 2015, the dominant sales were in the central region for the $20 \mathrm{ft}$. fan diameter. In 2017, the dominant sales volumes were from the southern region for the $20 \mathrm{ft}$. fan diameter. The trend line for the $24 \mathrm{ft}$. fan diameter shows that the sales fluctuate from the year of 2013 to 2015 and increase again in 2017.

\section{Market Forecasting}

Forecasting is important to improve product sales. Other than that, it is important to let the product remain competitive alongside technological demand. Technology intelligence, management issues, and technology roadmap are the main key elements in market forecasting [36]. Thus, in this paper, long-term forecasting is used to predict the upcoming sales for the next five years. Normally, forecasting needs to go through a few processes to define a result. This process starts with the purpose of forecasting, such as the product price estimation, or sales volume. Then, the process continues 
with an estimation of the dependent variables of forecasting. Lastly, the forecasting technique must use a suitable method to process the data. Usually, forecasting is accomplished by determining the market share and market sales by using forecasting techniques, which are qualitative and quantitative methods [37]. In this case, this study uses the quantitative method to predict future sales of monstrous fans based on existing products, technologies, prices, and market volume. The quantitative method basically stands on mathematical techniques, which are easy to apply by computer applications. Hence, in this paper, the forecasting process applies a moving average technique to define the forecasting result. This technique requires an average number of specified samples from past observations to go through the process. The sample is included in the tabular form and the forecasted results were defined by using Equation (1)-(3). The next section will explain the forecasting results of the monstrous fan.

$$
a+b x
$$

While,

$$
\begin{gathered}
a=\bar{y}-b \bar{x} \\
b=\frac{\sum(x-\bar{x})(y-\bar{y})}{\sum(x-\bar{x})^{2}}
\end{gathered}
$$

whereas $x$ and $y$ is the sample while $\bar{x}$ and $\bar{y}$ means the average

\subsection{Forecasting Analysis of Product Features}

Fan diameter size is a factor to consider during setup for installation. If the place has a large area, the fan diameter should be larger to ensure the air movement reaches all the area. Through the forecasting sales in Figure 13a and incremental percentage in Table 3, the trend line shows that the $24 \mathrm{ft}$. fan diameter sales will increase slightly from 2017 towards 2022. Overall sales for every fan diameter will experience an increase in sales. However, the demand for the $20 \mathrm{ft}$. fan diameter will decrease for the next five years starting from 2017, compared to the other three fan diameter sizes.

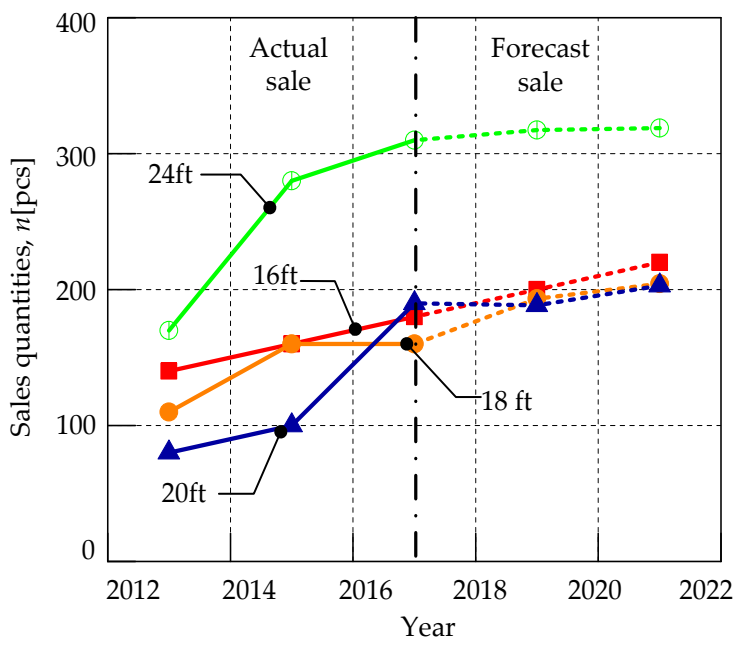

(a)

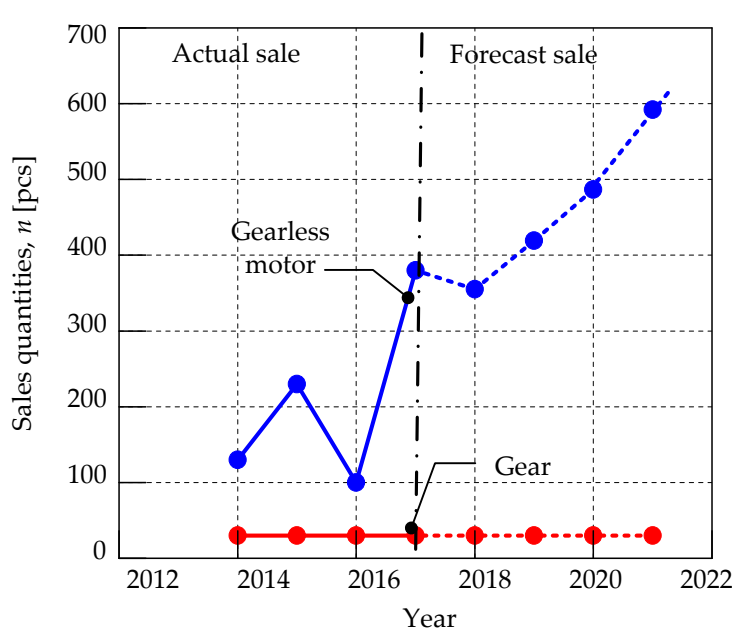

(b)

Figure 13. Forecasting analysis (a) Monstrous fan diameter forecasting (b) Monstrous fan technology forecasting. 
Table 3. Increment percentage of monstrous fan according to fan diameter.

\begin{tabular}{ccccc}
\hline \multirow{2}{*}{ Year } & \multicolumn{4}{c}{ Fan Diameter } \\
\cline { 2 - 5 } & $\mathbf{1 6} \mathbf{f t}$. & $\mathbf{1 8} \mathbf{f t}$. & $\mathbf{2 0} \mathbf{f t .}$ & $\mathbf{2 4} \mathbf{f t}$. \\
\hline 2013 & 140 & 110 & 80 & 170 \\
2015 & 160 & 160 & 100 & 280 \\
2017 & 180 & 160 & 190 & 310 \\
2019 & 200 & 193 & 188 & 317 \\
2021 & 220 & 204 & 202 & 319 \\
\hline Increment $(\%)$ & 11.11 & 13.34 & 18.9 & 9.2 \\
\hline
\end{tabular}

The gear is a mechanism used to drive the fan system. In the forecasting analysis from Figure 13b, it shows that the gearless motor shows an increment beginning in 2013 until a forecasted year after 2017. Table 4 shows that gearless technology is important to the monstrous fan industry due to its advantages. Gearless technology offers smooth performance and greater efficiency compared to gear driven technology. Furthermore, through the uses of gearless technology, there is no gearbox required and it needs less maintenance. This technology is said to produce quieter operation when the fan is running.

Table 4. Increment percentage of monstrous fan sales forecasting according to fan technology.

\begin{tabular}{cccccccccccc}
\hline \multirow{2}{*}{ Type } & \multicolumn{1}{c}{ Year } & \multicolumn{1}{c}{$\begin{array}{c}\text { Increment } \\
\text { (\%) }\end{array}$} \\
\cline { 2 - 11 } & $\mathbf{2 0 1 3}$ & $\mathbf{2 0 1 4}$ & $\mathbf{2 0 1 5}$ & $\mathbf{2 0 1 6}$ & $\mathbf{2 0 1 7}$ & $\mathbf{2 0 1 8}$ & $\mathbf{2 0 1 9}$ & $\mathbf{2 0 2 0}$ & $\mathbf{2 0 2 1}$ & 32.5 \\
Gearless motor & 80 & 130 & 230 & 100 & 380 & 355 & 419 & 486.7 & 591.9 & 0 \\
Gear & 30 & 30 & 30 & 30 & 30 & 30 & 30 & 30 & 30 & 0 \\
\hline
\end{tabular}

\subsection{Forecasting Analysis of Product Technology}

The electric motor is the main important part of a monstrous fan. The ability of a monstrous fan and its performance depend on the motor that drives the blade. Based on Figure 14a, the forecasting sales according to motor types showed that the induction motor still leads as the manufacturers' choice. The increased percentage as shown in Table 5 shows about $26.6 \%$ for an induction motor, $18 \%$ for a permanent magnet, $28.5 \%$ for a transverse flux, and $7.6 \%$ for a BLDC motor. The increment of the induction motor percentage sales is possible due to the price of an induction motor, which is cheaper than other motor types. Besides that, the simple construction and reliability of the fan industry attract manufacturers to use this type of motor compared to the permanent magnet and BLDC motor. Through forecasting, transverse flux will also experience a high increment number in sales. This increment is due to the influence of the branding name, which is able to provide a good perception towards end users.

Table 5. Increment percentage of monstrous fan forecasting according to motor types.

\begin{tabular}{ccccc}
\hline \multirow{2}{*}{ Year } & \multicolumn{4}{c}{ Types of Motor } \\
\cline { 2 - 5 } & Permanent Magnet & Induction Motor & BLDC & Transverse Flux \\
\hline 2013 & & 100 & 100 & 50 \\
2015 & 100 & 180 & 120 & 140 \\
2017 & 120 & 240 & 120 & 160 \\
2019 & 140 & 300 & 132 & 210 \\
2021 & 18 & 300 & 141 & 255 \\
\hline Increment $(\%)$ & 26.5 & 7.6 & 28.5 \\
\hline
\end{tabular}




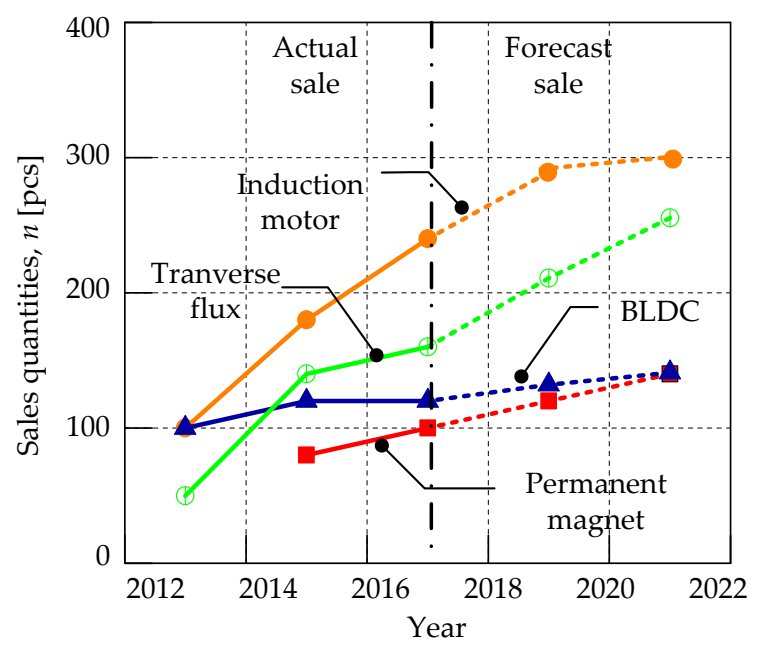

(a)

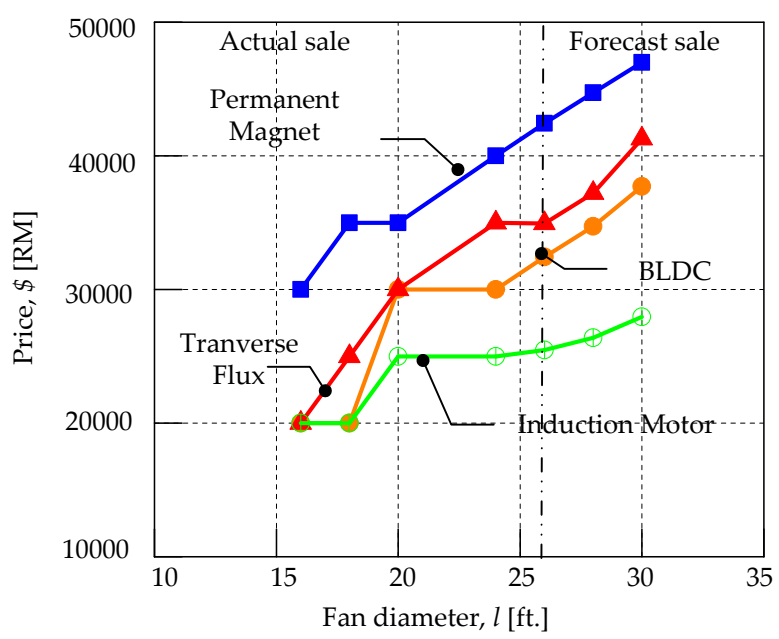

(b)

Figure 14. Product technology forecasting (a) Motor types sales (b) Motor price forecasting.

Pricing is important in business in order to expand business growth. There are a few factors that will affect the pricing of products, such as technology, consumer preference, and weather condition. Based on Figure 14b and Table 6, BLDC will experience a high increase in price after 2017, which is about a $14.6 \%$ increment. The induction motor has fewer increments, about $7.24 \%$. Based on the fan diameter, the larger fan diameter will affect the pricing due to its material surplus. The large volume of the fan will reflect the extension of fan blades and to drive the fan. All of these require an increase in material cost. The reason for the increasing percentage of BLDC price could be due to the add-on new technology that emerges in the BLDC motor. Nowadays, the BLDC motor type technology is required to use an electronic commutation to run the fan, which results in the rising costs of several additional features. However, a fan that uses an induction motor commonly uses conventional features to run the fan with such a resistance voltage controlled base. Thus, the increase in price for the induction motor is small [38].

Table 6. Increment percentage of Monstrous fan forecasting according to motor types.

\begin{tabular}{|c|c|c|c|c|c|c|c|c|}
\hline \multirow{2}{*}{ Types of Motor } & \multicolumn{7}{|c|}{ Fan Diameter [ft.] } & \multirow{2}{*}{$\begin{array}{c}\text { Increment } \\
(\%)\end{array}$} \\
\hline & 16 & 18 & 20 & 24 & 26 & 28 & 30 & \\
\hline Permanent Magnet & 30,000 & 35,000 & 35,000 & 40,000 & 42,428 & 44,714 & 47,000 & 10.6 \\
\hline BLDC & 20,000 & 20,000 & 30,000 & 30,000 & 32,428 & 34,714 & 37,714 & 14.6 \\
\hline Transverse Flux & 20,000 & 25,000 & 30,000 & 35,000 & 34,928 & 37,214 & 41,285 & 13.8 \\
\hline Induction Motor & 20,000 & 20,000 & 25,000 & 25,000 & 25,471 & 26,385 & 27,942 & 7.24 \\
\hline
\end{tabular}

\subsection{Forecasting Analysis of Market Shares}

Figure 15a depicts the forecasting analysis of a monstrous fan according to market distribution. From here, market distribution of the monstrous fan will have a high potential in the industrial sector after 2017 followed by the mosque or prayer hall area. A high potential increase in sales is for the industrial and warehouse sectors is possibly due to the growth of factories that require a larger scale fan to distribute air. Other market distributions that experience a high increase in sales are the automotive and train station. Through forecasting analysis, other market distributions such as aviation, agriculture, airport, and restaurant will experience static sales and require other alternatives to increase their sales. In the Malaysian agricultural sector, many barns or stables are built in open areas. Thus, this phenomenon affects the sale of monstrous fans in the agriculture sector. At the same time, airport and aviation sectors are nowadays equipped with air conditioning, thus reflecting 
sales of the monstrous fan. As a consequence of the static sale, the marketing department from the monstrous company should focus on these four market distributions, which can actually increase the company's sales.

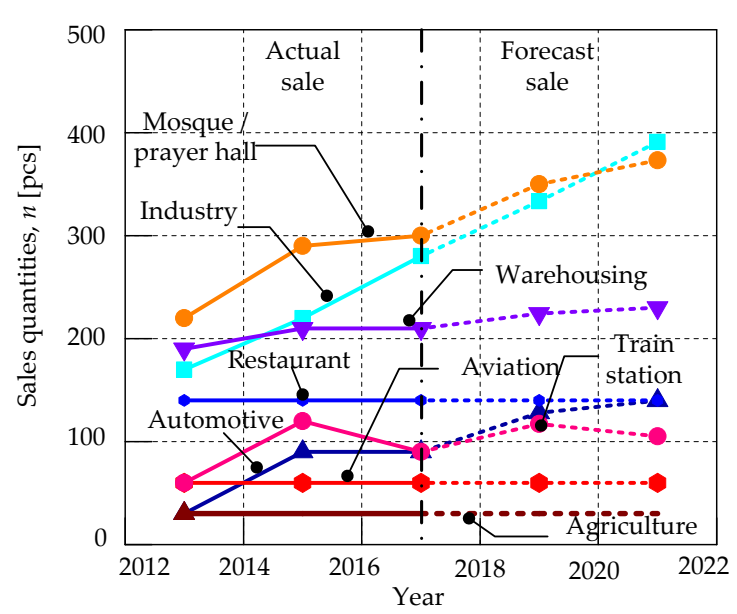

(a)

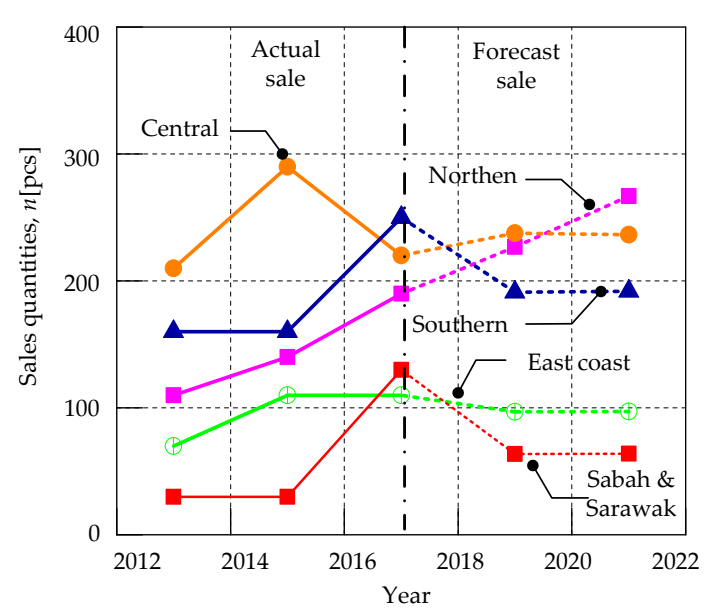

(b)

Figure 15. Market share forecasting (a) Market distribution (b) Market region.

Figure 15b shows the monstrous fan forecasting according to regions in Malaysia. The northern region shows a prospect in an increase of monstrous fan sales. The northern region, which covers the state of Kedah, Perlis, Perak, and Penang, has a potential possibility due to the rising number of factories and industries that are located mostly in Perak and Penang. Other regions such as the central region, southern, Sabah, and Sarawak, will experience fluctuating sales after 2017 according to the forecasted analysis. The decrease in sales volume that happens in the central and southern regions is possibly due to the market demand that has already used this product.

\section{Next Futuristic Monstrous Fan}

There are a few technological trends that have gradually begun to pick up. Future appliances are becoming smarter and more connected to other devices along with the rise of wireless charging technologies. Thus, ceiling fan technology is not left behind. Future monstrous fans are expected to have larger fan diameter to cover all spaces. It is expected that the fan diameter will be extended up to $30 \mathrm{ft}$. in length of the fan blade to meet user demand. Instead of extending the fan blade diameter, this monstrous fan is expected to come with an adjustable fan blade diameter, so that it can meet user needs based on certain range areas. Nevertheless, the extended fan diameter will reach saturated demand due to blade fatigue and safety reason. In the meantime, the bladeless technology for the monstrous fan will start to emerge.

The bladeless fan technology has emerged in 2009 by James Dyson and his team [39]. The bladeless fan works with the small size blades, which are located at the base. The concept of air movement in a bladeless fan adopted the fluid dynamics concept by sucking air and inducing it to flow within the surroundings of the fan ring tube. The ring tube features of the bladeless fan can be implemented on the monstrous fan as a hologram TV with some buttons for future research and development. Additionally, some features like warm and cold air flows are also available depending on the users' necessity. The sensor movement to detect the human body and capacity are also new features installed with the monstrous fan in order to attract the user. Due to the above, air conditioning device sales may suffer from lower sales.

The majority of monstrous fans are assembled on high ceiling levels. When the monstrous fan rotates, dust and dirt easily stick to the fan blades, which can cause the fan to be less efficient. Therefore, these monstrous fans will feature a vacuum concept on the top of the blade to remove dust. Moreover, 
it will also act as the ultimate machine cleaner for the large area when the sensor detects dirt on the area. Then, the fan automatically transforms to a vacuum mode and removes all the dirt and dust. Monstrous fans are big enough to produce energy. When the fan is turned off, the monstrous fan is still rotating and there is kinetic energy present, which is considered as energy loss. The energy loss will be converted into new electrical energy to turn on the monstrous fan again or other appliances. Thus, in the future, this monstrous fan is able to transform into a smart appliance in parallel with the technological development of today.

\section{Conclusions}

This paper aims to forecast product features, product technology, and the market share of monstrous fans. The main contribution of this paper is represented by specific knowledge on the technical specificities of monstrous fans in Malaysia, a country with an equatorial climate. There are a few findings that are key points for the market and greater sales information on monstrous fans, especially in regards to product features, technology, price competitiveness, and share of local markets. The findings have identified the product features of the monstrous fan that are constantly chosen by users, such as a large fan diameter. Product sales are dominated by the $16 \mathrm{ft}$. fan diameter and $24 \mathrm{ft}$. fan diameter, so as to meet the consumer requirement to distribute wider air circulation. Thus, the sales demand drops due to the perception of the end user, who requires large fan diameters to cover a larger area.

In conclusion, an extended fan diameter with the extra improvement found in monstrous fan efficiency is required. Another factor is the sale of the Induction Motor, which is high compared to other motors. Traditionally, this Induction Motor is widely used for the application of ceiling fans because of the technology maturity involved with it. Thus, it can be concluded that the Induction Motor will continue to be chosen in the future. But other types of motors, such as the BLDC motor and the Transverse Flux Motor with additional technology will gain attention from the market.

From the findings on technology and price competitiveness, the Permanent Magnet Motor and BLDC have a higher price compared to the other motor types. The presence of magnet material inside the fan and the controlling method of these two types of motors becomes the main reason for their high price. As an assumption, the prices of the monstrous fan will rise as a result of the material surplus and the rare earth magnet invention, which develops the electric motor. Furthermore, there are many types of Induction Motors being researched, which are intended to improve the motor because the prices of these motor types are still lower due to their construction. Moreover, the judgement on a monstrous fan's current technology is dominated by gearless technology. Gearless technology is quieter and provides less friction in the monstrous fan. The ability of the design features will influence other manufacturers to improve their monstrous fans in order to attract more users.

Regarding the market share findings on the market sales distribution, industrial and warehousing are markets where a high potential for sales exists. Other market sectors that also have potentials but lack a marketing strategy will see sales that remain static. It is advisable to the marketers to conduct more online advertisement through social media and provide awareness to users in terms of electricity consumption and the benefits of using a monstrous fan compared to air conditioning. If not, the monstrous fan industry will remain dormant by only providing service maintenance as a core business.

In conclusion, the monstrous fan is growing in the market section in Malaysia. The rapid growth in sale volumes of monstrous fans shows that this product requires greater improvements to make it marketable in the business world. The new technology for structure, fan blades, and motor types, will make this product energy saving and efficient. In the coming years, the monstrous fan is expected to have more additional features and become a multipurpose appliance. Thus, to support the reliability of this monstrous fan application, a survey on the public opinions towards this application must be discussed in greater depth. The anticipation for this paper shows that forecasting sales and technology for the monstrous fan is required. A similar study with a longitudinal design would allow for a more detailed analysis and would get around the problem of poor recall. Hence it would allow for more 
detailed information about the nature and evolutionary process of new and futuristic technological developments [40].

Author Contributions: R.N.F.K.R.O., N.A. and N.A.M.Z. conceived and conducting the survey; Amiruddin Ahamat, F.A.A.S. and K.A.K. contributed in analysis; and N.A. and R.N.F.K.R.O. wrote the paper.

Funding: The author would like to thank the Ministry of Education Malaysia, Universiti Teknikal Malaysia Melaka (UTeM) for providing research grants, GLUAR/PPRN/2017/FKE-CERIA/G00050, PJP/2017/FKE/HI12/S01537 and PJP/2017/FKE/HI12/S01538.

Acknowledgments: The authors also wish to acknowledge the contribution from all respondents in fulfilling the requests concerning monstrous fan information. Their gratitude is particularly for their help and the information received from Suria Giant Fan Sdn. Bhd., Benima Marketing Sdn. Bhd., Kolowa Ventilation (M) Sdn. Bhd., Masterglobal (HQ) Sdn. Bhd., Sunwins Sdn. Bhd., Best Fans Sdn. Bhd., Gard Inc. Sdn. Bhd., Syspex Tech (M) Sdn. Bhd., and Macro air (Khind Alliances) Sdn. Bhd.

Conflicts of Interest: The authors declare no conflict of interest.

\section{References}

1. Cheng Leong Goh. World climate types. In Resource Atlas in Physical Geography, 1st ed.; Pearson Education South Asia Pte Ltd.: Buona Vista Drive, Singapore, 2010; p. 12.

2. Gao, Y.; Zhang, H.; Arens, E.; Present, E.; Ning, B.; Zhai, Y.; Zhai, Y.; Zhai, Y.; Zhai, Y.; Pantelic, J.; Luo, M.; Zhao, L.; Raftery, P.; et al. Ceiling fan air speeds around desks and office partitions. Build. Environ. 2017, 124, 412-440. [CrossRef]

3. Zhai, Y.; Arens, E.; Elsworth, K.; Zhang, H. Selecting air speeds for cooling at sedentary and non-sedentary office activity levels. Build. Environ. 2017, 122, 247-257. [CrossRef]

4. Chen, Y.; Zhang, Y.; Tang, H. Comfortable air speeds for young people lying at rest in the hot-humid area of China in summer. Build. Environ. 2017, 124, 402-411. [CrossRef]

5. Saber, E.M.; Tham, K.W.; Leibundgut, H. A review of high temperature cooling systems in tropical buildings. Build. Environ. 2016, 96, 237-249. [CrossRef]

6. Liu, S.; Lipczynska, A.; Schiavon, S.; Arens, E. Detailed experimental investigation of air speed field induced by ceiling fans. Build. Environ. 2018, 142, 342-360. [CrossRef]

7. Hollist, J. Fanning Innovation in the HVLS Industry. Constr. Specif. 2017, 76-82. Available online: www. constructionspecifier.com (accessed on 5 January 2018).

8. Aynsley, R. Quantifying the cooling sensation of air movement. Int. J. Vent. 2008, 7, 67-76. [CrossRef]

9. Shah, N.; Sathaye, N.; Phadke, A.; Letschert, V. Efficiency improvement opportunities for ceiling fans. Energy Effic. 2014, 8, 37-50. [CrossRef]

10. Carlson, B.; Yourself, G.F. How HVLS Fan Benefit Small Business. 2018. Available online: www.gofanyourself. $\mathrm{com} / \mathrm{blog} /$ why-hvls-fans-are-the-better-choice/ (accessed on 20 March 2018).

11. Mahlia, T.M.I.; Moradalizadeh, H.; Zubir, M.N.M.; Olofsson, T. Theoretical and experimental investigation of energy efficiency improvement of the ceiling fan by using aerodynamic blade profile. J. Energy Environ. 2011, 3, 40-49.

12. HNEI Report. Ceiling Fan Study: Literature and Market Report; MKThink: San Francisco, CA, USA, 2017.

13. Aynsey, R. Fan size and energy efficiency. Int. J. Vent. 2016, 3315, 33-37. [CrossRef]

14. Atomberg Technologies. Ceiling Fan Blades. Fans. 2017. Available online: https://atomberg.com/ceiling-fanblade/ (accessed on 27 April 2018).

15. Sox, D. High Volume, Low Speed (HVLS) Fans from DuctSox. 2018. Available online: http://www. bladetecfans.com/Industrial.html (accessed on 24 July 2018).

16. Dewar, S.W. Whalepower Corporation and Tubercle Technology, Wordpress. Whalepower Brochure. Available online: https:/ / whalepowercorp.wordpress.com/our-technology / (accessed on 25 May 2018).

17. Jang, C.S.; Ross, J.C.; Cummings, R.M. Numerical investigation of an airfoil with a Gurney flap. AIAA Pap. 1992, 2708, 801-809. [CrossRef]

18. Ishak, D.; Tiang, T.L.; Choy, S.K. Performance evaluation of permanent split-capacitor single-phase induction motor for ceiling fan application. In Proceedings of the 2015 18th International Conference on Electrical Machines and Systems (ICEMS), Pattaya, Thailand, 25-28 October 2015; pp. 1865-1870. [CrossRef] 
19. Callahan, M.P.; Su, G.H. Development of a high efficiency ceiling fan. Proc. Twelfth Symp. Improv. Build. Syst. Hot Humid Clim. 2000, 1, 270-277.

20. Alagumariappan, P. Design and fabrication of high efficiency squirrel cage induction motor using finite element method. ARPN J. Eng. Appl. Sci. 2018, 10, 1852-1858.

21. Bhasme, N.; Durge, P. Comparative study of electrical motors for ceiling fan application. Int. J. Electr. Eng. Technol. 2015, 6, 976-6545.

22. De Almeida, A.T.; Ferreira, F.J.T.E.; Baoming, G. Beyond induction motors-Technology trends to move up efficiency. IEEE Trans. Ind. Appl. 2014, 50, 2103-2114. [CrossRef]

23. Vijayakumar, R.; Mohandass, M.P.; Angeline, S.S. An overview on performance improvement of an induction motors (im)-A review. Int. J. Innov. Res. Electr. Electron. Instrum. Control Eng. 2014, 2, 2019-2026.

24. Jaylin Krell. Big Ass Fans Comparison. Available online: https://macroairfans.com/blog/who-are-big-assfans / (accessed on 4 January 2018).

25. Zulkarnain, N.F.; Ibrahim, T.; Romlie, M.F. Design and optimization of permanent magnet machine for ceiling fan. In Proceedings of the 2016 6th International Conference on Intelligent and Advanced Systems (ICIAS), Kuala Lumpur, Malaysia, 15-17 August 2016; pp. 2-7.

26. Falco eMotors. EPOCH HVLS Fans; Falco eMotors Inc.: Pune, India, 2017.

27. Samadian, M. Performance And Cost Comparison Of Spoke-Type IPM And SPM BLDC Motor For Fan Application. In Proceedings of the 31th Power System Conference, Tehran, Iran, 24-26 October 2016; pp. 1-4.

28. Liu, C.S.; Hwang, J.C.; Chen, L.R.; Fu, C.C. Development of new structure of brushless DC servo motor for ceiling fan. In Proceedings of the 2009 4th IEEE Conference on Industrial Electronics and Applications, Xi'an, China, 25-27 May 2009; pp. 2640-2643. [CrossRef]

29. Danielsson, M.W. High Volume Low Speed Fan using Direct Drive Tranverse Flux Motor. U.S. Patent No 14/553,577, 28 May 2015.

30. Kim, K.; Cho, Y.; Hong, S. Geared Induction Motor Fault Diagnosis by Current, Noise and Vibration Considering Measurement Environment. J. Int. Counc. Electr. Eng. 2017, 7, 15-21. [CrossRef]

31. Takayama, N. High-speed and high-precision technology using direct-drive motor for five-axis machining center. J. Jpn. Soc. Mech. Eng. 2019, 111, 1075.

32. Fine, L.M. Selling and sales management. Bus. Horiz. 2007, 50, 185-191. [CrossRef]

33. Ahamat, A. Entrepreneurial Opportunity Creation in the Biotechnology Industry in Malaysia; University of Sheffield: Sheffield, UK, 2013; Available online: http:/ / etheses.whiterose.ac.uk/id/eprint/4021 (accessed on 30 January 2019).

34. California, S.; Emerging, E. Southern California Edison Emerging Products Dairy Farm Technologies, Southern California. 2013. Available online: http://www.etcc-ca.com/sites/default/files/reports/ et13sce7020_conductive_cooling_system_for_dairy_farms_report_final (accessed on 4 January 2018).

35. Kammel, D.W.; Kappelman, J.J. Design of high volume low speed fan supplemental cooling system in dairy freestall barns. In Proceedings of the International Dairy Housing Conference, Fort Worth, TX, USA, 29-31 January 2003; p. 13. [CrossRef]

36. Pressman, A.; Dairy Farm Energy Efficiency. National Sustainable Agriculture Information Service. Available online: www.attra.ncat.org/attra-pub/dairyenergy.html (accessed on 4 January 2018).

37. Savioz, P.; Blum, M. Strategic forecast tool for SMEs: How the opportunity landscape interacts with business strategy to anticipate technological trends. Technovation 2002, 22, 91-100. [CrossRef]

38. Chindia, E.W. Forecasting Techniques and Accuracy of Performance Forecasting. Int. J. Manag. Excell. 2016, 7,813-820. [CrossRef]

39. Top Cooling Fan. Secret behind Dyson Bladeless Fan-All That You Need to Know. Available online: https:/ / www.topcoolingfan.com/how-dyson-bladeless-fans-work/ (accessed on 16 March 2018).

40. Ahamat, A.; Chong, S.C. Assessment of the factors influencing entrepreneurs on the biotechnology business venture. In Proceedings of the 24th International Business Information Management Association Conference-Crafting Global Competitive Economies, Milan, Italy, 6-7 November 2014; pp. 2171-2177.

(C) 2019 by the authors. Licensee MDPI, Basel, Switzerland. This article is an open access article distributed under the terms and conditions of the Creative Commons Attribution (CC BY) license (http:/ / creativecommons.org/licenses/by/4.0/). 